\title{
Husserl's Early Concept of Metaphysics As the Ultimate Science of Reality
}

\section{Emiliano Trizio}

University of the West of England

emilianotrizio@hotmail.com

Reception date: 04-10-2017

Acceptance date: 13-11-2017

\begin{abstract}
This article reconstructs the development of Husserl's definition of metaphysics as the ultimate science of reality in the courses and lectures written up to the year 1905. The analysis of these texts casts light on Husserl's philosophical self-understanding in the wider context of late Nineteenth Century German philosophy as well as on the fundamental role that metaphysical interests played in the development of his thought from its earliest stage. A particular attention is devoted to Husserl's early views about the relation between the theory of knowledge and metaphysics, whose analysis is a necessary preliminary step to address the theoretical issue of the relation between transcendental phenomenology and metaphysics.
\end{abstract}

Keywords: Husserl, Metaphysics, Theory of Knowledge, Phenomenology

\section{Introduction}

The relation between Husserl's thought and metaphysics has been approached in a number of different ways. The questions that, by far, have attracted more attention since Husserl's own time revolve around the so-called metaphysical neutrality of phenomenology. In particular, readers of Husserl have tried to understand whether pre-transcendental phenomenology could be considered in some sense "metaphysically neutral" and whether and to what extent the

\footnotetext{
${ }^{1}$ See, for instance, Benoist 1997, Zahavi 2001.
} 
transcendental turn implies forsaking such neutrality or, perhaps, even embracing a form of metaphysical idealism. Consequently, a number of publications address questions such as whether phenomenological idealism is itself a metaphysical thesis, or whether it has metaphysical implications at all ${ }^{2}$. Directly related to this series of investigations, there lies the general theoretical issue of understanding whether Husserl's phenomenology implies the adherence to the metaphysics of presence ${ }^{3}$, as Heidegger maintained, and whether this is to be deemed as a fatal flaw undermining Husserl's entire project. More recently, the metaphysical implications of Husserl's phenomenology have been also explored in relation to the by now not so recent revival of metaphysics within analytic philosophy. In this sense, for instance, one has discussed the relevance of phenomenological descriptions for the analytic debates concerning the so-called "metaphysics of consciousness" 4

Since these investigations are often motivated by the desire to situate Husserl's thought in the context of contemporary philosophy, thereby probing its relevance or fruitfulness for current debates, it is not surprising that the vast majority of the literature in this field should question the relation between phenomenology and metaphysics, so to speak, from the outside, i.e., by employing the word "metaphysics" in one or another among its pre- or extraphenomenological senses. In this paper, I will second the choice of those who take the opposite path, and try to contribute to the exploration of Husserl's own notion of metaphysics, as a preliminary step to any theoretical assessment of the metaphysical implications of transcendental phenomenology ${ }^{5}$. More precisely, I will analyze the genesis of the chronologically first sense in which Husserl himself employed this term, namely, metaphysics as the ultimate

\footnotetext{
2 For an earlier strong metaphysical reading of Husserl's transcendental idealism, see Landgrebe 1949, and, more recently, Moran 2005. Attempts to underplay the metaphysical implications of phenomenology are to be found in Carr 1999, Crowel 2001. On this question, see also Zahavi 2002, 2010, and Zahavi and Boucher 2008. For a systematic criticism of the misunderstandings surrounding the notion of phenomenological absolute, see Majolino 2016.

${ }^{3}$ See Bernet 1982.

${ }^{4}$ See, for instance, Marbach 2010.

5 See, for instance, Bancalari 2010, and De Santis' forthcoming article on metaphysics in the Cartesian Meditations. On the relation between metaphysics and the crisis of European sciences, see Trizio 2016.
} 
science of reality. It is my hope that this kind of investigations will eventually help cast light on the general issues I have briefly outlined above, which will constitute the broader horizon surrounding this paper.

Husserl often spoke about metaphysics at least in two different senses: 1) the conversion of the empirical sciences of nature and spirit into the ultimate sciences of reality by means of a systematic philosophical critique of their presuppositions as well as their results, 2) the reconsideration of the world of nature and spirit from an ethical, teleological, and theological sense ${ }^{6}$. In a famous and often quoted formulation, Husserl characterizes the second layer of metaphysical analyses, as the research concerning the problematic of "...the irrationality of the transcendental fact that emerges in the constitution of the factual world and of spiritual life: thus, metaphysics in a new sense." ${ }^{7}$ This problematic is connected with what, in a number of texts from the Cartesian Mediations to the Krisis, Husserl calls the "highest and ultimate questions" concerning morality, religion and the problems of the sense of humane existence, of history, and of the entire word ${ }^{8}$.

Now, the limited aim of this paper is to focus on the early versions of the first aforementioned concept of metaphysics, which Husserl develops in the unpublished lectures and courses up to the year 1905, i.e., at the time Husserl was moving away from the approach of the Logical Investigations and was developing the insights that would lead to transcendental phenomenology. A point of interests of these writings is that, in contrast with the Logical Investigations, where metaphysical problems are mentioned only in passing and without offering a general characterization of their nature, they contain explicit attempts to define the scope of metaphysics as a science. I will show that the first versions of this notion of metaphysics were already at work before the Logical Investigations, and that in the years following the publication of this work, Husserl develops a complex (albeit provisional and still incomplete) account of metaphysics that allows us to appreciate the central role of this kind of researches for the elaboration of his entire philosophy.

\footnotetext{
${ }^{6}$ See, for instance, Hua XXVIII, p. 182, Hua VII p. 187-188.

${ }^{7}$ Hua VII, p. 188.

${ }^{8}$ For instance, Hua VI, pp. 6-7.
} 


\section{Husserl's first formulations of the concept of metaphysics}

Some hints about the metaphysical problems arising from the critical analysis of empirical sciences are to be found as early as 1892-93 in the texts that Husserl wrote in view of the publication of a volume on the concept of space (the so-called Raumbuch), which never saw the light of the day ${ }^{9}$. However, while these texts mention metaphysical problems in a way that is fully compatible with Husserl's subsequent treatments of the problem, they contain no general and explicit formulation of the nature and task of metaphysics. For an early explicit statement concerning the nature of metaphysics, we can instead turn to the Logik Vorlesung 1896, in which, while characterizing the nature of pure logic as the science of science, Husserl evokes an issue that will play a fundamental role throughout his career, up until the Krisis, namely that of the incompleteness of the sciences, and, specifically of the empirical sciences. After claiming that those sciences are unable, by themselves, to satisfy our theoretical interest for reality, ${ }^{10}$ Husserl explains that they need, in the first place, a clarification of their metaphysical presuppositions. Among the latter, Husserl includes:

...dass es eine Außenwelt gibt, welche nach Raum und Zeit ausgebreitet ist, dass alles reale Werden dem Kausalitätsgesetz unterliegt, dass Widersprechendes realiter nicht existieren könne u.dgl.; Voraussetzungen, die zum Teil außerordentlich inhaltsreich sind. Ich erinnere nur an die Annahme eines realen Raums von der Beschaffenheit einer mathematischen dreidimensionalen euklidischen Mannigfaltigkeit mit jener unübersehbaren Fülle von Gesetzen, welche die euklidische Geometrie kennen lehrt ${ }^{11}$.

\footnotetext{
${ }^{9}$ For instance, Hua XXI, p. 265 and pp. 270-71 where Husserl defines the metaphysical problems of space as those concerning the reality corresponding to our representation of space.

10 "Wir müssen es als eine wichtige Tatsache anerkennen, dass alle Wissenschaften, so wie sie jetzt vorliegen, der systematischen Vollendung, der ausreichenden theoretischen Begründung ermangeln, die wir im Interesse einer vollen intellektuellen Befriedigung von ihnen fordern müssen." Hua Mat I, p. 4.

${ }^{11}$ Hua Mat I, p. 5.
} 
This list of presuppositions looks, in the face of it, rather heteroclite, because it contains assumptions concerning the existence of the world (i.e., a matter of fact, albeit a singularly significant one), its causal order, and the specific structure of its spatiotemporal form (which, in Husserl's language will always count as synthetic a priori principles), as well as a purely formal principle stemming from the objective conversion of the principle of contradiction as it is formulated in the realm of pure significations, namely a formal ontological principle (i.e., analytic). However, it is clear that these assumptions are needed in order to provide a general characterization of what all empirical sciences take for granted in their theoretical exploration of the totality of real being of which each of them investigates but a single portion. As Husserl's preoccupation is to characterize metaphysics as a science, it follows that metaphysics must consist in a unitary theoretical body corresponding to a unitary object-domain, rather than in a disconnected series of foundational/critical investigations that could be carried out in the framework of multiple already existing sciences. Accordingly, he adds that the mere fact that those presuppositions lie at the basis of all empirical sciences and thus concern the whole of reality, and, further, that they cannot become an object of investigation by adopting the same methods used by those sciences entails that a science of a new type is called for $^{12}$. However, the fact that these presuppositions are not studied by the different sciences, while implying that investigations based on new methods are called for, does not already establish that a unitary discipline will encompass the study of this cluster of presuppositions. In the next sections, we will see that clarifying the scope and unity of metaphysics will constitute a significant challenge in the following years of Husserl's philosophical activity.

Husserl's characterization of this science in the Logik Vorlesung 1896 will provide the real starting point of this study:

Man nennt sie heutzutage gewöhnlich Erkenntnistheorie, aber sie ist im Wesentlichen identisch, oder identisch einem Teil nach, mit der altehrwürdigen Metaphysik, der Ersten Philosophie des Aristoteles. Nur vermeidet man gern einen Namen, der durch hohle Irrlehren unseres Jahrhunderts einen schlechten

${ }^{12}$ Ibid. 
Beigeschmack erhalten hat. Die Wissenschaften bedürfen also fürs Erste einer metaphysischen Grundlegung. Darunter ist aber nichts weniger gemeint als eine dialektische Herausspinnung der konkreten Resultate dieser Wissenschaften aus einer abstrakten Begriffs mystik, sondern, viel bescheidener und fruchtbarer, eine nüchterne Klärung und Prüfung jener allgemeinen Voraussetzungen, welche die Wirklichkeitswissenschaften über das reale Sein machen, und in weitergehender wissenschaftlicher Arbeit die Herstellung der gereiftesten und letzten Erkenntnis vom realen Sein, von seinen Elementen, Formen und Gesetzen, die der jeweilige Stand der Einzelwissenschaften, der deutera philosophia, wie sie Aristoteles nennt, gestattet ${ }^{13}$.

Husserl claims that this sought-for science is, in his time, habitually referred to as the theory of knowledge, although it is either identical or identical in part with the time-honored metaphysics, that Aristotle called first philosophy. It is important to stress that while this passage seems to suggest that the theory of knowledge is in fact identical or partly identical with metaphysics (the latter, as we shall see, will indeed be Husserl's own position, at least in some sense and for some time), when taken literally, it actually contains a weaker claim. This claim is that the science dealing with the aforementioned presuppositions of empirical sciences concerning real being is today named theory of knowledge, while that science is identical or partly identical with good old metaphysics or first philosophy. In point of logic, this claim is even compatible with a restrictive redefinition of the theory of knowledge that would altogether expunge metaphysical questions thus understood from its scope. What is still missing, in other words, is an explicit delimitation of the fields of the theory of knowledge and metaphysics. Instead, Husserl makes the following terminological point that is functional to his intention of rescuing the term metaphysics from the disrepute brought upon it ${ }^{14}$ : without yet providing a full account of the actual relations existing between the theory of knowledge and the science whose task is to clarify the presuppositions about real being underlying the sciences of the world, one has to acknowledge that that science

\footnotetext{
13 Ibid.

${ }^{14}$ Which, of course, does not mean that, at that time, Husserl had not already worked out the main traits of his position concerning the relations between the theory of knowledge and metaphysics.
} 
deserves to be called metaphysics, no matter how much its questions tend to be regarded today as belonging to the theory of knowledge.

We will have shortly the opportunity to see to what extent Husserl does not share the disdainful attitude of many of his contemporaries for the word metaphysics, and for what it evokes. For the moment, it is important to stress that this metaphysical foundation of science does not consist in what Husserl calls "dialectical reveries" ("dialektische Herausspinnung") over the results of the sciences, but to the already mentioned clarification and grounding of "those general presuppositions that the sciences of reality make about real being", followed by a critical work that, so to speak, distills from the results of the special sciences the implications for the portions of being they investigate, in other words, what is their current contribution to the ultimate knowledge of reality.

This being said, we still need to come to a better understanding of the notion of metaphysics thus understood, as well as of its unity as a science, and, on the basis of the passage just quoted, we know that this can be accomplished only by clarifying the relations between metaphysics and the theory of knowledge. Husserl's solution to this problem will be the main subject of the next two sections.

\section{Theory of knowledge and metaphysics in the years preceding the publication of the Logical Investigations}

A text dated 1898/99 and reproduced in the third of the Materialbände under the title Aus der Einleitung der Vorlesung "Erkenntnistheorie und Hauptpunkte der Metaphysik" is of fundamental importance to reconstruct the evolution of Husserl's attitude towards metaphysics as well as to begin addressing the issues mentioned at the end of the previous section. Furthermore, it provides precious elements to trace the remarkable continuity with which this connection has hiddenly motivated so much of Husserl's intellectual development. In addition, we find here succinct and clear, albeit unoriginal sketches of the philosophical moods dominating German speaking philosophy in the second half of the Nineteen Century, supplemented by emphatic statements of Husserl's own attitude towards it, which cast light of what his goals were already before the 
publication of the Logical Investigations. The aim of these lectures is explicitly declared a few pages after the beginning, namely to present the theory of knowledge as the most fundamental philosophical discipline and to clarify a number of key-points of metaphysics ("Hauptunkte") immediately following ("nächststehender") the theory of knowledge, and that constitute, at present, the parts of metaphysics more accessible to a rigorous treatment ${ }^{15}$. However, toward the end of this text, Husserl specifies that explaining why and how the fundamental questions concerning the relation between knowledge and being determine our entire conception of reality and, thus, are connected to the above mentioned key-points of metaphysics, allows him to exemplify and illustrate how little our empirical sciences are able, by themselves, to satisfy our theoretical interest concerning reality, and to what extent metaphysics, as a supplementary science is necessary to this end ${ }^{16}$. This exemplification is, throughout the text, accompanied by several other examples of more specific unquestioned presuppositions underlying empirical sciences, which help flashing out the entire scope of metaphysics thus understood. In other words, this text revolves around two interrelated issues: 1) the relation between the theory of knowledge and metaphysics, and 2) the characterization of the incompleteness of empirical sciences as a way to assert the legitimacy and necessity of a scientific metaphysics that goes "beyond them", while being built on them ${ }^{17}$. While discussing these two issues, Husserl provides at least a partial clarification of his notion of metaphysics. Let us take up these two issues in turn, beginning with the problematic relation between the theory of knowledge and metaphysics.

\footnotetext{
15 "Meine Vorlesungen stellen sich zur Aufgabe, die Erkenntnistheorie als die allen anderen wissenschaftlichen Disziplinen vorangehende und ihnen das Fundament beistellende philosophische Wissenschaft darzustellen und in Zusammenhang mit ihr eine Reihe ihr nächststehender Hauptpunkte der Metaphysik klarzulegen. Ich kann geradezu sagen: „die“ Hauptpunkte der Metaphysik; nämlich der Metaphysik, soweit sie als Wissenschaft gegenwärtig entwickelt ist.” Hua Mat III, p. 230.

${ }^{16}$ Hua Mat III, p. 251.

${ }^{17}$ Husserl, while reminding the reader of the classical anecdote about the fortuitous origin of the name "metaphysics" (which, according to a certain tradition, was invented by Andronicus of Rhodes), observes that, in some sense, also in light of his own characterization, this science goes "beyond" the science of nature (Mat III, p. 233).
} 
Several important claims are made in the introductory remarks (pp. 226330): 1) the theory of knowledge ("Erkenntnistheorie") and metaphysics are two deeply intertwined fundamental chapters of philosophy ("Hauptgebiete"), whose definition, reciprocal delimitation, and even fundamental distinction are still much disputed ${ }^{18}$. Husserl identifies two main parties: those who believe that the theory of knowledge and metaphysics make up only one discipline, and those who believe that they are two "essentially different disciplines having equal rights". Within the first party, he further distinguishes between, on the one hand, those who believe that this single discipline is metaphysics, and that the theory of knowledge is only a part of it, and, on the other, those who believe that this single discipline is, instead, the theory of knowledge, which would also set itself the task to show the impossibility of metaphysics in the traditional sense (i.e., presumably, the kind of metaphysics criticized by Kant) ${ }^{19}$. 2) Not only their mutual demarcation ("gegenseitige Abgrenzung"20), but also their relations to other scientific disciplines is the object of widespread controversy. More specifically, it is debated whether "... beside and beyond the special sciences of physical and psychic reality also a metaphysics could enjoy an autonomous legitimacy. In addition, there is disagreement as to how the relation of the theory of knowledge to logic and psychology is to be intended." ${ }^{21}$ 3) In spite of the uncertainty surrounding these issues, the theory of knowledge is the discipline fundamental not only to metaphysics, but also to the totality of philosophy and to the worldview stemming from it, in the sense that it is

\footnotetext{
${ }^{18}$ Hua Mat III, p. 225.

19 "Viele Forscher wollen hier nur eine Disziplin gelten lassen; die einen, weil sie die Erkenntnistheorie nur als ein Kapitel der Metaphysik gelten lassen, die anderen, weil sie beide Disziplinen geradezu identifizieren. Das Letztere betrifft alle die Philosophen, welche den eigentlichen Hauptstamm der metaphysischen Probleme, um die sich die Philosophie von Jahrtausenden abgemüht hat, als unlösbar, als die menschliche Erkenntnisfähigkeit wesentlich überschreitend ablehnen und nur eine kritische Disziplin von der Erkenntnis zugestehen wollen, zu deren Aufgabe es gehöre, die prinzipielle Unlösbarkeit dieser Probleme darzutun, also die Unmöglichkeit einer Metaphysik im traditionellen Sinn. Auf der anderen Seite gibt es aber eine Reihe von Denkern, welche Erkenntnistheorie und Metaphysik als wesentlich unterschiedene und gleichberechtigte Disziplinen auffassen.” Hua Mat III, p. 225-27.

${ }^{20}$ Hua Mat III, p. 226.

21 Ibid.
} 
instrumental for them, to the point that Husserl does not hesitate to claim that the theory of knowledge also functions as a "Werkzeug" for metaphysical research ${ }^{22}$.4) Again, in spite of the aforementioned points of disagreement, the entire modern philosophical tradition has been unanimous in acknowledging the foundational role of the theory of knowledge within the universe of philosophical disciplines, while German idealism has represented a failed attempt to lead an assault on "... the Olympus of philosophy with dialectical arts" undertaken by a race of philosophical "titans" thereafter precipitated into the "... dark Tartarus of disagreement and unclarity" ${ }^{23}$. The end of the romantic metaphysical adventures has thus led to the return to Kant as the great "theorist of knowledge, who had set limits to the claims of an uncritical metaphysics and placed the critique of knowledge as the true foundation of all philosophy. ${ }^{24}$ " The current situation is largely the same, adds Husserl, and after recent waves of new metaphysical work that Husserl dismisses without specifying what he is referring to, the theory of knowledge is back on center stage, facing the new challenge represented by the positivism of Mach and Avenarius.

As for point 1), it is important to notice that Husserl, in this text, does not explicitly endorse any of the three alternatives he considers. To be sure, Husserl would not have sided with those who think that the theory of knowledge absorbs what is left of metaphysics once it has shown the impossibility of its traditional version (the second sub-option). An entire portion of this lecture reasserts that, if the demise of the metaphysics of German idealism has been by itself a positive thing, the positivistic dismissal of metaphysics à la Comte has hindered the development of a necessary and rightful aspiration to metaphysical knowledge, without the satisfaction of which, the fall into irrationalism is

\footnotetext{
22 "Wir aber wollen eine Philosophie haben; wir wollen sie uns durch sorgsamste Analyse und Kritik erarbeiten. Nach dem Prinzip, dass nur die vollste Klarheit und Deutlichkeit der Begriffe eine sichere Erkenntnis ermöglicht, werden wir aller Verschwommenheit und Vieldeutigkeit von vornherein den Krieg erklären. Bis zu den letzten absolut sicheren Fundamenten der Erkenntnis wollen wir graben, um auf sie eine echte und zuverlässige Theorie des Wissens (zu bauen) und damit auch ein sicheres Werkzeug metaphysischer Forschung zu gewinnen.” Hua Mat III, p. 228.

${ }^{23}$ Hua Mat III, p. 229.

${ }^{24}$ Ibid.
} 
inevitable ${ }^{25}$. Husserl, thus, vehemently proclaims his belief that, once the concept of metaphysics is clarified, it will appear that such science lies within the scope of what our cognitive capacities can achieve ${ }^{26}$. Furthermore, given that Husserl here characterizes the theory of knowledge also as an instrument for metaphysics, it would seem that the first sub-option is ruled out too: how can the theory of knowledge be a chapter of metaphysics if it is to be used as an instrument for it? Furthermore, it is a claim reiterated several times in these years, that the fatal flaw of all modern theories of knowledge (including Kant's) is that they were not able to establish a theory of knowledge free from metaphysical presuppositions, i.e., an authentic pure elucidation of livedexperiences of which our knowing ultimately consists ${ }^{27}$. It would, thus, appear that Husserl's position is represented by the third option: the theory of knowledge and metaphysics are two distinct disciplines. However, as we are about to see, things are more complicated than that.

Once more, as it will happen in many subsequent texts, Husserl undertakes the elucidation of the concept of metaphysics using Aristotle's classical definition of first philosophy as a starting point. For Aristotle, first philosophy was the discipline dealing with what characterizes being in general (being as

25 "Die metaphysischen Bedürfnisse bleiben unbefriedigt, die Metaphysik selbst gilt, nach dem Vorgang Comtes, als ein Überbleibsel zurückgebliebener wissenschaftlicher Epochen, auf eine Stufe zu stellen mit Alchemie und Astrologie; dafür aber blühen Spiritismus und Okkultismus, Aberglaube jeder Art wagt sich breit zu machen - ganz wie Beneke dies prophetisch vorausgesehen hat." Hua Mat III, p. 232. It is noteworthy that Husserl quotes a long passage from the work of the Nineteenth Century German metaphysician Friedrich Eduard Beneke (1798-1854) System der Metaphysik und Religionsphilosophie aus den natürlichen Grundverhältnissen des menschlichen Geistes abgeleitet, published in Berlin in 1840, in which metaphysics is characterized in a characteristically modern way as dealing with knowledge of ourselves, the world, and "das Übersinnliche", Ibid., pp. 230-231. Once more, it appears that Husserl, while adopting a cautious step-by-step strategy in the exploration of metaphysics, holds on to the broadest interpretation of its scope.

26 "Dass eine Wissenschaft von der Art der Metaphysik möglich und berechtigt ist, dass sie in die Sphäre menschlicher Erkenntnisfähigkeit fällt, das wird sich nun alsbald herausstellen, wenn wir den Begriff der Metaphysik und die ihr zugehörigen Probleme erwägen." Hua Mat III, p. 233.

${ }^{27}$ As is well known, already in those years, Husserl reasserts several times over the principle that the theory of knowledge must be free from any metaphysical presupposition. See, for instance, Hua Mat III, p. 84. 
such), and preceding all other sciences that investigate only a portion of being ${ }^{28}$. Although Husserl, this time, adds immediately that Aristotle's definition “... is too narrow and in the need of a certain clarification" 29 , it does build on what he deems to be Aristotle's key-insight, namely that the first principles of being in general must be common to all special sciences and logically precede their own experimental and theoretical developments. We find here the same claim about the existence of metaphysical presuppositions of natural science contained in the Logik Vorlesung 1896 and subsequently in $§ 7$ of the Prolegomena, but spelt out in a more detailed way and with a different emphasis. Let us delve into the details of this analysis.

All special sciences, we read, take for granted a host of presuppositions inherited from the prescientific, natural (natürlich) standpoint: not only that the world exists, but that it contains things and processes standing in mutual causal connections and, furthermore, a multiplicity of subjects likewise causally interconnected with one another and with other components of reality. ${ }^{30}$ To be sure, scientists step-by-step modify the assumptions of the layman, but they never radically question these general presuppositions ${ }^{31}$. In a close and problematic connection with these assumptions, scientists are likewise oblivious of the riddles affecting their own theoretical operations, i.e., of the

${ }^{28}$ Ibid., p. 233.

${ }^{29}$ Ibid., p. 234.

30 "Den Dingen und den Erkenntnisfragen steht er [the natural scientist] eigentlich genauso naiv gegenüber wie der natürliche Mensch vor aller Wissenschaft. Er nimmt eben, wie wir vorhin sahen, die Denkarbeit des natürlichen Bewusstseins auf. Die umgebende Welt mit ihren Dingen, Vorgängen, Verhältnissen, Regelmäßigkeiten der Aufeinanderfolge und Koexistenz findet er schon vor, und er folgt nur den im Gegebenen liegenden Motiven zur Modifikation seiner ersten oder schrittweise gewonnenen Überzeugungen.” Mat. III, p. 235. This passage anticipates the famous pages of Ideas I describing the natural attitude even in the use of terms such as "Umgebung" to refer to the different spheres of taken-for-granted objects (Hua III/1, pp. 56-58), "vorfinden" to designate the uncritical acquaintance with the world characterizing the natural attitude (Hua III/1, pp. 56-61), and "Vorfindlichkeiten" to indicate the posits of the natural attitude themselves (Hua III/1, p. 61).

31 "Die Begriffe, mit denen sie operieren, entnehmen sie der vorwissenschaftlichen Weltauffassung, mit der sie selbst auch beginnen. Modifizierend gehen sie Schritt für Schritt weiter, sie wenden die Begriffe so um, wie sie es für ihren Zweck, für die Gesetzeserkenntnis brauchen; aber auch nicht mehr.” Hua Mat III, p. 251. 
difficulties laying in the possibility for our mental operations to secure access to such reality. The fundamental question of the theory of knowledge is here touched upon: how can a subjective process such as perception or judgment gain the right to yield objectively valid knowledge? ${ }^{32}$ In his more mature writings, and especially after the transcendental turn, Husserl often asks this question in order to develop the basic ideas of the theory of constitution and to highlight how transcendental phenomenology embraces all meaningful problems traditionally ranked under the heading of the theory of knowledge ${ }^{33}$. Husserl's strategy, here, differs in a significant, and I would say, interesting way, which the introductory and programmatic nature of this text can explain. Husserl shows that different answers to the problem of the possibility of objective knowledge lead to completely different conceptions of the being of reality, which, in turn, deeply affect the ultimate value of scientific knowledge itself, while leaving untouched its prima facie theoretical content. What we find here is the idea of a fundamental interdependence between the essence of knowledge and the interpretation of the being of reality as such, exemplified through a variety of classical positions. The aim is to highlight that scientists, because of their uncritical acceptance of the natural standpoint, and because of their predominant interest in the practical mastery of nature, leave the fundamental epistemological questions open, from which the entire conception of the being of reality ultimately depends ${ }^{34}$. This point will always provide the core of the phenomenological "critique" of science.

Husserl mentions solipsism, consciousness-idealism ("Bewusstseinidealismus"), and positivism: i.e., a doctrine, or, better, a whole family of doctrines, which denies the existence of material reality independently of all

\footnotetext{
${ }^{32}$ Hua Mat III, p. 241.

33 The article of 1917 Phänomenologie und Erkenntnistheorie, reprinted in Hua XXV pp. 125-205, contains particularly clear statements of this relation (see, in particular, Hua XXV, §§ 32-39).

34 “...die mannigfaltigen Erfahrungswissenschaften zwar immerfort von der Wirklichkeit reden, über sie lehren, in Betreff ihrer Hypothesen und Gesetze formulieren und dabei doch nicht (das), was im letzten Grund die Wirklichkeit ist, erforschen, weil ihre Tendenz auf Orientierung in der Welt und auf ihre praktische Beherrschung gerichtet ist statt auf die innerste Erforschung ihres Seins..." Mat. III, p. 245.
} 
mental life ${ }^{35}$. The subsequent position considered by Husserl is Kant's, which he interprets as one close to idealism, but with the addition of the assumption of unknowable things in themselves corresponding both to what we experience as our internal life and to the external world ${ }^{36}$. Again, we have here an ontological picture of reality deeply intertwined with an attempted solution of the riddles of knowledge. Beneke and Arthur Schopenhauer are briefly mentioned as original developments of Kant's philosophy ${ }^{37}$. Once more, their ways of departing from Kant's conception of "reality" stem from their different appraisal of our capacity to access the inner nature of things, and, more specifically, the being attested in our own inner life ${ }^{38}$. The last point of view mentioned by Husserl is realism, which in this list we find, not by chance, at the opposite end side of solipsism. Realists are characterized as the thinkers closer to common sense, of course, but, more interestingly, as those who believe that

...die Zweifel über die Objektivität der Erkenntnis sich lösen lassen, ohne $<$ dass> die Grundzüge der Weltauffassung, wie sie sich schon im gewöhnlichen Leben ausgebildet haben, dadurch wesentlich tangiert würden. ${ }^{39}$

Realists, thus, admit the possibility of the knowledge of the material world and the existence of two kinds of reality: psychic and physical. ${ }^{40}$

The way Husserl closes this list of examples perfectly illustrates its real aim:

Die Beispiele genügen ja, um zu zeigen, wie die schwierigen Grundfragen nach der Objectivität der Erkenntnis dahin tendieren, unsere ganze Auffasssung vom

\footnotetext{
${ }^{35}$ Hua Mat III, p. 238.

36 Ibid., p. 239.

${ }^{37}$ Ibid., pp. 239-40.

${ }^{38}$ Schopenhauer's views about the relation between natural science and metaphysics, while not explicitly playing a significant role in the epistemological debates of the end of nineteenth century, deserve to be recalled because they provide a post-Kantian redefinition of the boundaries between these two disciplines, and, thereby, of the distinction between appearance and reality itself.

${ }^{39}$ Hua Mat III, p. 240.

${ }^{40}$ Ibid.
} 
Sein der Welt zu bestimmen, und dass der möglichen Ansichten hier viele sind. ${ }^{41}$

We begin with a certain natural conception of reality, which is also taken for granted by all special sciences; we then realize that this conception, when critically scrutinized, leads back to the questions of the theory of knowledge. Finally, we realize that different solutions to these questions imply different conceptions of the being or reality.

Thus, the answer to question concerning the objective validity of knowledge acts as a field of force capable, so to speak, of deforming the metaphysical scaffolding of the world, i.e., our entire conception of the being of the world. Realism appears precisely as that position that altogether rejects, or tries to minimize, the deformation of everyday worldview produced by the riddles concerning the possibility of objective knowledge. This interdependence between the theory of knowledge and the interpretation of being is much more interesting than the trivial repercussions of a theory of knowledge on the worldview based on it, which are due to the fact that one's theory of knowledge determines what the possible objects of reliable knowledge are. This is of course true: for instance, different degrees of skepticism about the range of objects accessible to our knowledge would indeed result in worldviews whose "ontological population" varies accordingly. However, here, the problem does include, but also reaches far beyond than that of determining what counts as an object of possible knowledge, for it concerns the interpretation of the being of everything we believe to exist and to be knowable at any level of objectivity and in any sense. An obvious example is, once more, Kant's theory of knowledge, which makes the entire natural world, inasmuch as it is studied and determined by the natural sciences, "degrade" to a phenomenal being, beyond which, if one is to follow the most common reading of Kant, as Husserl does, there lies the unknowable thing in itself. This kind of considerations allows Husserl to connect his analyses to the epistemological status of the existing empirical sciences. In few paragraphs, Husserl shows that those sciences do not in fact and cannot in principle completely satisfy the theoretical interest from which they themselves stem, i.e., they cannot come to an ultimate

\footnotetext{
${ }^{41}$ Hua Mat III p. 241.
} 
understanding of the being they investigate, and this precisely because they do not question the natural standpoint within which they operate ${ }^{42}$. This must be, therefore, the task of a different science:

Diese Wissenschaft ist, wie ich nicht zu sagen brauche, die Metaphysik. Sie hat zu erforschen, was dem Seienden in letztem Grunde zukommt; und damit in innigstem Zusammenhang stehen, wie wir letzthin sahen, die Fragen nach den obersten Erkenntnisprinzipien, die uns das Erreichen der realen Wahrheit ermöglichen sollen und von deren Lösung die Bestimmtheiten, die wir dem realen Sein zuschreiben, so wesentlich abhängen. ${ }^{43}$

This passage contains an explicit definition of metaphysics as a science that investigates what ultimately "pertains" to what is, and whose investigation must be carried out in connection with the questions concerning the highest principles of knowledge.

After this brief characterization of the relation between the theory of knowledge and metaphysics, and, in particular, of the dependence of the keypoints of metaphysics on the kind of answer that one gives to the problem of knowledge, let us now turn to the above mentioned second fundamental theme of this text, namely to a more explicit and detailed characterization of the incompleteness of empirical sciences, and, consequently, of the thematic horizon of metaphysics as the science completing them. Given that such incompleteness always consists in the uncritical acceptance of presuppositions on the part of the empirical sciences, an account of at least the main different kinds of such presuppositions is necessary. Since Husserl discusses over and over this theme on the basis of different examples ${ }^{44}$, it is advisable to sum up what results from his various incomplete expositions.

42 "Bei diesen schwierigen und erfolgreichen Bestrebungen liegen aber dem Erfahrungsforscher die Fragen nach dem Wesen der Erkenntnis und des Seins, die Fragen, worauf sich der Objektivitätswert der Erkenntnis stützt und was das erkannte Sein im letzten Grund ist, gänzlich fern" Hua Mat III, p. 242. My emphasis.

43 Hua Mat III, p. 245, my emphasis. Husserl also calls metaphysics "Wirklichkeitswissenschaft kat'exochen", the science of reality par excellence, ibid.

${ }^{44}$ Hua Mat III, pp. 234-235, 246-251, 251-252. 
At the most general level, Husserl distinguishes between those assumptions on reality that are common to all sciences, and those explaining specific groups of phenomena and, thus, pertaining to a special science ${ }^{45}$. The former are "tacit and wholly unproved" 46 assumptions, while latter are explicit. In the first group we find presuppositions that are easy to make explicit, such as "the world exists" or one of another formulation of the principle of causality; however Husserl, much more often, lists, under the heading of general assumptions about reality, concepts, or better fundamental concepts ("Grundbegriffe") ${ }^{47}$. What he means is that such concepts stand in need of clarification and elaboration, which will show us, in the first place, "what in consideration of reality we are entitled to assume and what we are not" ${ }^{\prime 4}$. In other words, these concepts are fundamental components of implicit assumptions about reality that are not critically scrutinized. The following is the most comprehensive list of fundamental concepts in this text: "Thing and property, cause and effect, matter and energy, being and appearance, to come into existence and to decay, unity and multiplicity, space and time, etc." ${ }^{\prime 4}$ Some of these concepts are purely formal in character and, hence, belong to the field of pure logic. And indeed, Husserl immediately adds that the value for the exploration of reality of a great quantity of general propositions belonging to pure logic and pure mathematics is taken for granted in the scientific exploration of reality ${ }^{50}$. What Husserl does not explicitly say is that the assumptions of this last type concern the whole of reality and yet they are not tacit. Hence, they should form a group apart, as indeed they do according to Husserl himself. Husserl spends some words to illustrate questions connected to the classical Aristotelian problem of a

\footnotetext{
${ }^{45}$ Hua Mat III, p. 246.

46 Ibid.

${ }^{47}$ Hua Mat III, p. 249, pp. 251-252.

${ }^{48}$ Hua Mat III, p. 252.

${ }^{49}$ Hua Mat III, pp. 251-252.

${ }^{50}$ Hua Mat III, p 252.
} 
clarification of the different senses of being ${ }^{51}$, to the notion of substance and change $^{52}$, and to the paradoxes of movement ${ }^{53}$.

After these fundamental concepts and presuppositions concerning the whole of reality, Husserl considers the second group of assumptions, namely the explicit hypotheses pertaining to the individual sciences ${ }^{54}$. A question that presents itself at this point is the following: why would the elucidation of such hypotheses belong to metaphysics, as Husserl maintains, if the thematic space of metaphysis is opened up precisely by the existence of unquestioned assumptions concerning the whole of reality? In other words, is there a tension between the quasi-Aristotelian way in which Husserl introduces the concept of metaphysics, and his claim that also the elucidation of the special sciences' conceptual material falls within the scope of metaphysics $?^{55}$ The answer lies, presumably, in the nature of the metaphysical elaboration of the conceptual material of the special sciences. Metaphysics is not called for to replace existing scientific theories with new ones, but only to clarify their sense on the basis of the deeper and more general insights into the nature of reality that are gained in

\footnotetext{
${ }^{51}$ Hua Mat III, p. 247.

52 "Die einen identifizieren dann diesen tragenden Hintergrund oder dieses Wesen der Erscheinungen mit der Materie der Physik, die anderen hingegen mit den Kräften, die sie als etwas Seelenartiges auffassen, beim Menschen aber als die Seele selbst; sie ist die verborgene Substanz des Dinges, das wir Mensch nennen.(...) Während wir so auf der einen Seite subtile und weit ausgesponnene Untersuchungen über das Wesen der Substanz als des unbekannten Trägers der Eigenschaften und als des inneren Seins der Dinge finden, hören wir auf der anderen Seite, all diese Forschungen seien nichtig, es gebe keine Substanzen, sondern nur Komplexionen von Eigenschaften." Hua Mat III, p. 249.

${ }_{53}^{53}$ Hua Mat III, p. 250-251.

${ }^{54}$ This passage contains a list of useful examples taken from the natural sciences of the time: "Auf der anderen Seite gibt es besondere Annahmen der einzelnen Erfahrungswissenschaften, z.B. die verschiedenen Gattungen und Arten von Molekülen und Atomen in ihren substantiellen Besonderungen und Gruppierungen, die mannigfaltigen Arten von longitudinalen und transversalen Schwingungen, der Äther mit seinen wunderbaren Eigenschaften, in älterer Zeit die verschiedenen Fluida u.dgl. Hierher gehören die besonderen Gesetze der Physik, Chemie, Physiologie usw., soweit sie wirklich sind, als was sie ausgesprochen werden, Gesetze, die auf die wirkliche Welt zu gehen beanspruchen.” Hua Mat III, p. 247.

${ }^{55}$ A claim that, as we have seen, Husserl had made already in the Logik Verlesung 1896.
} 
the critical elucidation of the first group of assumptions. In other terms, this second, more applied part of metaphysics is edified in light of the results of the first, more classically Aristotelian part of metaphysics that deals, one could say, with reality qua reality. Thus, the kind of elucidation that is here in question is one that is made possible by the integration of those sciences (of "second philosophy") into the unitary edifice of the ultimate science of reality and receives its sense only in virtue of it. Under this interpretation, thus, the aforementioned tension is eliminated.

It is now possible to conclude this analysis of the 98'/99' lecture, by drawing some general conclusions about Husserl's early notion of metaphysics. This text shows that, before the publication of the Logical Investigations, Husserl already believes that the theory of knowledge functions as an instrument for a metaphysics consisting in the ultimate clarification of reality as investigated by the empirical sciences. In light of this, it would be a mistake to think that, in contrast with what will happen after the transcendental turn, at the time of the Logical Investigations, Husserl saw phenomenology (that is the discipline that, for Husserl, takes up the fundamental questions of the theory of knowledge) as an enterprise disconnected from metaphysics (let alone anti-metaphysical). Precisely the opposite is true: already at the time of the Logical Investigations Husserl considers that the gigantic task of the elucidation of knowledge that phenomenology has undertaken is motivated by the desire to build a philosophy in the most general sense, a philosophy in which metaphysics as the ultimate science of reality is a fundamental chapter.

However, the relation between the theory of knowledge and metaphysics is still affected, at this stage, by a certain unclarity and so is, therefore, the identity of metaphysics as a science. This unclarity is reflected by some of Husserl's claims concerning precisely the key-points of metaphysics that are so intimately connected to the theory of knowledge. In particular, if adjudicating between what Husserl calls "metaphysical convictions" (such as idealism, positivism, Kantianism, and realism) or ruling all of them out, in favor of a radically different general account of being (which this texts leaves open as a possibility and which will indeed be Husserl's own solution, once transcendental idealism is in place) is something carried out within the theory of knowledge, then the mutual

\footnotetext{
${ }^{56}$ Hua Mat III, p. 255,
} 
delimitation between the former and metaphysics stands in need of further clarification. As we have seen, Husserl characterizes the key-points of metaphysics as those metaphysical issues that stand closer to the questions of the theory of knowledge. Towards the end of the text, however, we find two passages that connect them to the theory of knowledge in an even more intimate way:

Bei der Kürze der uns zu Gebote stehenden Zeit wird es besser sein, uns sogleich möglichst direkt in die Grundfragen (zu) vertiefen, die unter dem Namen der erkenntnistheoretischen teils eine allgemeine Voraussetzung aller Wissenschaften bilden und teils auch, gefasst in besonderer Beziehung auf das Sein an sich, als fundamentale Fragen der Metaphysik gelten müssen ${ }^{57}$.

Daraus entspringen nicht bloß erkenntnistheoretische, sondern schon metaphysische Überzeugungen der Art, wie wir sie in der Einleitung berührt haben, die Lehren des Bewusstseinsidealismus und Positivismus, der alle Erkenntnis auf die subjektiven Phänomene einschränkt im Gegensatz zum Realismus, der eine Erkenntnis von transzendenten Wirklichkeiten für möglich und für uns erreichbar anerkennt ${ }^{58}$.

This first passage (which, to be sure, is not terribly clear) states that the "Grundfragen" that go under the name of "erkenntnistheoretisch" in part form the epistemological background of all the sciences, in part, in so far as they are grasped in specific relation to being in itself, must also be reckoned among the fundamental questions of metaphysics. I take the expression "all sciences" to refer to the empirical as well as the logical and mathematical ones. Under this reading, Husserl is here referring to the fact that there are fundamental questions of the theory of knowledge such as "what is truth?", "how can a subjective lived-experience grasp an objective content whatsoever?", "how can an ideally identical judgment be reiterated at different times and by different subjects?", which, in their generality, refer to the possibility of knowledge of any object whatever, including numbers and purely logical objects. In this generality, these questions are not directly metaphysical in character, because metaphysics is, for Husserl, concerned solely with real being and not with ideal

\footnotetext{
${ }^{57}$ Hua Mat III, p. 252.

${ }^{58}$ Hua Mat III, p. 255. My emphasis.
} 
objects. On the other hand, there are "other" fundamental questions of the theory of knowledge that result from narrowing down the same aforementioned general questions to the knowledge of the real-transcendent being ("Sein an sich") investigated by empirical sciences. ${ }^{59}$

The second passage refers exclusively to the problem of real transcendence and states that the already mentioned general positions such as idealism and realism are, by themselves, not only epistemological, but also already metaphysical. In sum, these two passages suggest that the theory of knowledge is either already a part of metaphysics (when it deals with the problem of real transcendence), or, (when it deals with the possibility of knowledge in general) a discipline that, in virtue of a redirection of its focus on real being, can be apprehended as a part of metaphysics. To be sure, this claim does not conflict with the aforementioned metaphysical neutrality of the theory of knowledge, for Husserl assigns to the theory of knowledge the task of establishing the first general principles of metaphysics. In other words, its results would also constitute the first chapter of metaphysics, in such a way that no metaphysical claims would count as a presupposition for the work of the theorist of knowledge. Yet, there is indeed a tension between these claims and the thesis that the theory of knowledge functions as an instrument for metaphysics, because, now, the theory of knowledge appears to be also the first level of the edifice of metaphysics. Under this interpretation, among the three alternative conceptions of the relation between the theory of knowledge and metaphysics considered at the beginning of this section, Husserl would seem, surprisingly, to opt for the one that makes the theory of knowledge, as a unitary discipline, a part of metaphysics. We will see that the courses written in the years following the Logical Investigations cast some light on this issue as well as on other aspects of Husserl's "early" concept of metaphysics.

\footnotetext{
${ }^{59}$ It should be added that, as we have seen, also mathematical and logical principles belong to the uncritically accepted presuppositions of empirical sciences (obvious example, the principle of contradiction that Husserl had evoked already in the 1896 lecture), and, consequently, also the part of the theory of knowledge that focuses exclusively on these principles can be apprehended as a contribution to the metaphysical clarification of reality as posited by the empirical sciences.
} 


\section{Formal and material metaphysics in the years preceding the transcendental turn}

Some useful, if cursory remarks on the nature of metaphysics can be found in the course Logik 1902/036 ${ }^{60}$, in the Allgemeine Erkenntnistheorie Vorlesung 1902-0361, and in the Urteilstheorie Vorlesung 190562. Those remarks are in line with the position so far outlined, but provide further insights into Husserl's views about the subject as well as conceptually significant terminological novelties that can help clarify the relation between the theory of knowledge and metaphysics.

In the course Logik 1902/03, Husserl outlines the task of metaphysics in a very succinct and effective way. Once more, Husserl begins by recalling that "Metaphysics is, as Aristoteles puts it, "First Philosophy""63 and that, for Aristotle, it is the science of "what pertains to being in generality" 64 . This time, however, he explicitly explains why he believes that Aristotle's definition is too narrow: granted that the polysemy of the general concept of being, and the particular problems connected to "being in the sense of reality" 65 raises many difficulties, the very nature of the problem at hand requires a broader interpretation of Aristotle's definition. It is such broader science that, according to Husserl, corresponds to the modern conception of metaphysics ${ }^{66}$. In light of our results, the nature of the problem in question is the ultimate determination of reality that goes beyond the provisional and relative one offered by the empirical sciences. Indeed, Husserl identifies the broader scope of metaphysics with the already mentioned assumptions that are common to all the sciences, and whose elucidation makes possible the ultimate interpretation of the being they investigate. Although Husserl does not repeat it here, we now know that the problem of the polysemy of the word "being" defines only a portion of these questions. Finally, Husserl reformulates the opposition between metaphysics and

\footnotetext{
${ }^{60}$ Hua Mat II.

${ }^{61}$ Hua Mat III.

${ }^{62}$ Hua Mat V.

${ }^{63}$ Hua Mat II, p. 11.

64 “... was dem Seienden in Allgemeinheit zukommt.” Ibid.

65 “... Sein im Sinne der Realität. ” Ibid.

66 Ibid.
} 
the special sciences of physical and psychical nature as the opposition between "the science of absolute being and absolute determinations of being" and the sciences in relative sense ${ }^{67}$. It is noteworthy that what is here meant by "absolute being" is nothing but the being that attests itself as real in light of the critique of the unproved principles underlying the special sciences ${ }^{68}$.

The Allgemeine Erkenntnistheorie Vorlesung 1902-03 briefly mentions again the problem of the mutual delimitation of the theory of knowledge and metaphysics and the aforementioned disagreement as to whether they should count as one and the same discipline or as two distinct ones. Once more, Husserl does not explicitly endorse either of the conflicting views, nor does he name any of their advocates. However, the thesis that one should maintain the distinction between the two is formulated in a way that, to say the least, resonates with Husserl's general approach:

Während die Metaphysik, sagen sie, die letzte Seins- und Welterkenntnis bieten will, die uns aufgrund der Einzelwissenschaften zugänglich, aber nicht in ihnen selbst gegeben ist, komme das reale Sein für die Erkenntnistheorie nur in hypothetisch allgemeiner Weise in Betracht, nämlich nur als Korrelatum von Erkenntnis und Wissenschaft; nur von den in den Ideen Erkennen und Sein gründenden Notwendigkeitsbeziehungen, nicht aber von dem, was nun tatsächlich und in letztem Grund ist, habe sie zu handeln ${ }^{69}$.

Both the theory of knowledge and metaphysics, according to this point of view, deal with real being, but real being becomes thematic within the theory of knowledge only in so far as there obtain necessary relations grounded in the ideas of knowledge and being that set general conditions for any real being whatever.

67 "Danach kann die Metaphysik auch als Wissenschaft vom absoluten Sein oder von den absoluten Seinsbestimmungen definiert werden, im Gegensatz zu den Einzelwissenschaften, die nur Wissenschaften im relativen, d.i. im vorläufigen, für die praktische Orientierung in der Erscheinungswelt und für die praktische Naturbeherschung zureichenden Sinne.” Hua Mat II, p. 12.

68 "Selbstverständlich ist unter den Titel absolutes Sein an keinerlei mystisch Überspanntheiten zu denken, sondern es handelt sich ganz nüchtern um das Sein, das sich uns als das wirkliche aufgrund der Kritik der Einzelwissenschaften und die ihnen ungeprüft zugrunde liegenden Prinzipien herausstellt.” Hua Mat II, pp. 12-13.

${ }^{69}$ Mat. III, pp. 9-10. 
The real being in question in the theory of knowledge is, thus, considered $e x$ hypothesi, whereas metaphysics aims to determine what in fact exists, based on the results of the special sciences. That this is, at bottom, Husserl's own view is indicated by that fact this distinction between metaphysics and the theory of knowledge reflects the distinction between fact and essence, and that, according to Husserl, the theory of knowledge must investigate and elucidate the essence of knowledge. Under this reading, Husserl would now side with the view that the theory of knowledge and metaphysics are actually two distinct disciplines. This seems to contradict the conclusion of the previous section, where it appeared that the theory of knowledge is already the first stage of metaphysics, and, hence, it can be included in it. However, as we shall now see, the terminology of the Urteilstheorie Vorlesung 1905 is finally able to dissolve these tensions and to highlight the unitary approach that surfaces throughout the different texts so far analyzed.

In this lecture, Husserl gratifies us with a detailed series of definitions of the various disciplines that we have encountered so far. 1) Pure logic is the "science of the ideal constituents and laws of theory in general, or [...] the science of truth and objectivity in general. Conceived so broadly, as it must be conceived, pure logic is identical with the mathesis universalis." ${ }^{, 70}$ Note that formal ontology is included in the mathesis universalis and results from a conversion of the logical truths to the realm of pure objectivity. 2) The theory of knowledge is the discipline intimately connected to pure logic that studies the relations between "truth and objectivity, on one side, and judging and knowing truth and objectivity respectively on the other." "11 Given that pure logic already sets general laws that must be valid for any object whatever, and given that the theory of knowledge determines the sense of knowledge, but also the sense of the being grasped in knowing, pure logic and the theory of knowledge jointly make up formal metaphysics ${ }^{72}$ or the formal science of being ${ }^{73}$, i.e., the part of the ultimate science of being that does not make assertions about (nor

\footnotetext{
${ }^{70}$ Hua Mat V, p. 41.

71 Ibid.

${ }^{72}$ Hua Mat V, p. 29.

${ }^{73}$ Hua Mat V, p. 41.
} 
presupposes) any factual being ${ }^{74}$. Indeed, the expression "Sinn des Seins", which will be of fundamental importance for Husserl's transcendental idealism, already appears in this lecture as a problem title for formal metaphysics ${ }^{75} .3$ ) Rooted in formal metaphysics is material metaphysics ${ }^{76}$ or metaphysics in the authentic sense ${ }^{77}$, which determines "what now factually, in categorial sense, is, what pertains to real being not only in general and as such, but de facto according to the results of the specific sciences of being." 78 4) The text also adds that phenomenology of knowledge, as "the descriptive discipline of the essence of thought" is the only possible terrain for the solution of the problems of the theory of knowledge ${ }^{79}$.

With the aid of these definitions, we can now try to dissolve the tensions that we have previously pointed out. What is the relation between the theory of knowledge and metaphysics? Are they one or two disciplines? At this stage, Husserl appears to answer along the following lines. If one defines metaphysics as the science of what ultimately pertains to real being in full generality, then one must admit that the theory of knowledge (as well as pure logic) is a part of metaphysics, and, more specifically, the formal part of metaphysics. In particular, the theory of knowledge, by investigating the sense of being of reality, addresses problems that in a misguided way (at this point one is entitled to add) have traditionally motivated metaphysical positions such as idealism and realism. However, metaphysics in the authentic sense, for Husserl, is only the one that investigates what, based on the empirical sciences, is in fact true,

\footnotetext{
${ }^{74}$ In this text, Husserl already stresses the difference between his understanding of the theory of knowledge (and of the "skeptical" attitude inbuilt in it) and Descartes'. A consequence of the purely "formal" character of Husserl's theory of knowledge is that the solution to its problems would in no way modify the theoretical content of the special sciences (whether a priori or empirical), Hua Mat V, p. 35. This prefigures another overarching theme of transcendental phenomenology, i.e., the opposition to any metaphysics positing "metaphysical substructions" (Hua VII, p. 235) and its replacement by the elucidation of the sense of being of reality accomplished by the theory of transcendental constitution.

${ }^{75}$ Hua Mat V, p. 29.

${ }^{76}$ Hua Mat V, p. 29.

${ }^{77}$ Hua Mat V, p. 41 ,

${ }^{78}$ Hua Mat V, pp. 41-42.

${ }^{79}$ Hua Mat V, p. 42.
} 
and not only the "formal" or "general" structure of being. The difference in both object and methodology between this authentic a posteriori metaphysics and the theory of knowledge fully justifies the claim that we are confronted with two different disciplines. Furthermore, the theory of knowledge can also be considered as an instrument for authentic metaphysics in this sense. In sum, Husserl adopts a nuanced intermediate solution between the two opposing parties mentioned already in the 1898/99 lecture, because, while acknowledging that the theory of knowledge and metaphysics are two thematically and methodologically distinct disciplines, one of which is fundamental to the other, there is also a sense in which they both directly contribute to the understanding of what real being ultimately is.

Let us however notice that, in spite of its clarity, the classification of disciplines presented in Urteilstheorie Vorlesung 1905 fails to specify what discipline would deal with some of the unclarified presuppositions on which empirical sciences rest. In section 2, the list of such presuppositions mentioned in the Logik Vorlesung 1896 appeared heteroclite and in need of clarification. Such list was expanded and, to an extent, clarified in the 1898/1899 lecture, as we have seen in section 3. In the Urteilstheorie Vorlesung 1905, some of these assumptions, being the object of pure logic, fall in formal metaphysics, some others, such as the existence of the world (or better, at this stage, the sense of its existence), must be clarified by the theory of knowledge and, hence, belong to formal metaphysics too, finally, the properly empirical ones, which are dealt with in the process of clarification of the content of the empirical sciences, pertain to material metaphysics. However, general a priori presuppositions about reality such as those of geometry or those pertaining to the notion of causality do not find a place here. They are a priori, but not purely formal, and they by no means belong to the theory of knowledge, nor to the broader field of phenomenology. Thus, the characterization of metaphysics presented in the Urteilstheorie Vorlesung 1905, while clarifying the relation between the theory of knowledge and metaphysics remains incomplete. In the Einführung in Logik und Erkenntnistheorie 1905/06, a course in which Husserl already presents a version of the phenomenological reduction, we find an attempt to fill this gap by introducing the notion of an a priori ontology of the real, which deals 
precisely with these a priori truths about reality. ${ }^{80}$ Regretfully, the terminology introduced there clashes with the one of the Urteilstheorie Vorlesung 1905, for this a priori ontology of reality is called [sic] "formal metaphysics", although Husserl immediately specifies that the term is inappropriate.

The a priori ontology of the Real is, we could again say, formal metaphysics, though, the term is better avoided. Metaphysics in the authentic sense is material metaphysics. The former, we could further say, is a priori, the latter, a posteriori metaphysics. The former is prior to all empirical sciences; the latter comes after the empirical sciences ${ }^{81}$.

An analysis of this course, however, would already lead us beyond the limited scope of this study, as does the subsequent developments of Husserl's thought, whereby the a priori ontology of the real will be in turned articulated in the a priori ontological disciplines pertaining to the different ontological regions.

\section{Conclusion: metaphysics as the horizon of Husserl's thought}

We have enough elements to draw some conclusions concerning Husserl's notion of metaphysics before the so-called transcendental turn. Husserl's thought was motivated from the outset by the project of developing a philosophy corresponding to the highest ambitions of the European tradition. In this programmatic framework, metaphysics presents itself as the crowning discipline, the one dealing with the fundamental questions concerning the totality of the real being of the world and of anything that might lie "beyond it". Within this approach, Husserl does not appear to be preoccupied by the

\footnotetext{
${ }^{80}$ Hua XXIV, pp. 95-102; 1984, pp. 93-99.

${ }^{81}$ Hua XXIV, p. 102; 1984, p. 99. The use of the expression "formal metaphysics" in this context is certainly motivated by the fact that the a priori ontology of the real, while not purely formal in the sense of pure logic, can be said to investigate "the a priori form of reality". Note also that the material metaphysics here mentioned coincides, instead, with that of the Urteilstheorie Vorlesung 1905. Finally, note that the term "material" does not refer to the Husserlian notion of material a priori. What Husserl calls "material a priori disciplines", such as geometry, here fall, instead, in the a priori ontology of the real.
} 
complex historical evolution of the concept of metaphysics from Aristotle's characterization up to its Kantian and post-Kantian developments. Rather, as is typical of his method, he appropriates a motive from the tradition and elaborates it in light of the theoretical developments and the resulting constraints characterizing his philosophical situation. The situation in question is one marked by the collapse of German idealism, by the rise of the anti-metaphysical stance of various forms of positivism, and by an often-exclusive focus on the theory of knowledge in name of a one-sided return to Kant. To use a term that, for better or worse, will play a significant role in Husserl's philosophy only several years later, the situation of metaphysics is one of crisis. Husserl's reaction to this crisis consists in the first place in fastening metaphysics in the strongest possible way to the soil of the theory of knowledge, conceived de jure as the fundamental philosophical discipline, and yet, at the same time, as a discipline de facto motivated by metaphysical interests. Further, it consists in provisionally restricting the thematic focus to the parts of metaphysics that are contiguous to the theory of knowledge. Finally, it consists in turning to the empirical sciences for the conceptual material on which an authentic science of real being must be built. The result of these three moves is the project of developing, first of all, a metaphysical foundation of the sciences of nature and of the psyche grounded in the parallel development of a mathesis universalis and of a pure theory of knowledge. As we have seen, a more precise characterization of this project implies an uneasy redefinition of the relation between the theory of knowledge and metaphysics, a redefinition that forces Husserl, at times, to struggle with his terminology and to modify it in ways whose underlying substantial significance should not be overestimated.

The more Husserl tries to be faithful to the spirit of what he regards as the Aristotelian notion of first philosophy, the more it appears that also the mathesis universality and the theory of knowledge should count as metaphysics, i.e., as the formal or a priori part of it. The former contains laws that are a priori valid for any being, while the latter determines the sense of being of the world, and rules out its wrong metaphysical interpretations. On the other hand, the more Husserl identifies the proper aim of metaphysics with the determination of what in fact exists in an ultimate and irrelative sense, the more metaphysics appears to be only the factual science of reality that results from elucidating empirical sciences by means of the essential insights gained by the mathesis universalis and by the 
theory of knowledge ${ }^{82}$ Husserl moved decidedly towards the second solution, by stressing that the authentic metaphysics can only be the one that speaks of what in fact exists. And, indeed, the solution outlined in the Urteilstheorie Vorlesung 1905 will not enjoy an enduring fortune in Husserl's corpus. Already in the in course Einführung in Logik and Erkenntnistheorie 1905/06, Husserl introduces significant terminological changes. Neither formal logic, nor the theory of knowledge are now treated as the a priori part of metaphysics, not even in a nonauthentic sense, ${ }^{83}$ while the theory of knowledge is, nonetheless, characterized as first philosophy ${ }^{84}$, signaling that Husserl is abandoning the traditional identification between first philosophy and metaphysics. ${ }^{85}$ Let us add, that in the lecture delivered in Göttingen in 1909 Einführung in die Phänomenologie der Erkenntnis, Husserl will be even more adamant in sharply distinguishing the theory of knowledge from metaphysics and in claiming that the former is not metaphysics, but only the foundation for $i^{86}$. In turn, the denomination of first philosophy will be coherently used for phenomenology itself ${ }^{87}$. In short, after the transcendental turn, the characterization of metaphysics in terms of knowledge of the ultimate facticity will become even stronger. By that time, however, transcendental phenomenology will provide a clearer sense in which a factual being can be said to be ultimate.

\footnotetext{
${ }^{82}$ Subsequently, Husserl will add the different material ontologies to the stock of eidetic sciences that take part in the foundation of empirical sciences.

${ }^{83}$ Only in a footnote Husserl still refers to formal-ontological truths as belonging to formal metaphysics, see Hua XXIV, p. 100, 1984, p. 97. As we have seen at the end of the previous section, the expression "formal metaphysics" appears once more in that course, but as a synonym of a priori ontology of the real.

${ }^{84}$ Hua XXIV, p. $157 ; 1984$, p. 155.

${ }^{85}$ It is indeed worth mentioning that in the 1905/1906 course the usual reference to Aristotle's notion of metaphysics is followed by an almost dismissive programmatic statement: "Today, we shall understand metaphysics itself differently, and more broadly." Hua XXIV, p. 96; 1984, p. 93.

86 “...Erkenntnistheorie als Wissenschaft bezieht sich auf Erkenntnis überhaupt. Sie ist nicht selbst Metaphysik, sondern das Fundament aller Metaphysik." Hua Mat VII, p. 37.

${ }^{87}$ Hua Mat VII, pp. 92-99.
} 


\section{Bibliography}

BANCALARI, S. (2010). «Eidos versus intersoggetività: una prospettiva husserliana sull'impossibile», Archivio di Filosofia, 78(1): 229-238.

BENoIst, J. (1997). Phénoménologie, sémantique, ontologie, PUF, Paris 1997. Bernet, R. (1982). «Is the Present Ever Present? Phenomenology and the Metaphysics of Presence», Research in Phenomenology, 12: 85-112.

CARR, D. (1999). The Paradox of Subjectivity. The Self in the Transcendental Tradition, Oxford: Oxford University Press.

Crowell, S. (2001). Husserl, Heidegger and the Space of Meaning, Evaston: Northwestern University Press.

DE SANTIS, D. (Forthcoming). «"Metaphysische Ergebnisse”: Phenomenology and Metaphysics in Edmund Husserl's Cartesianische Meditationes ( $\$ 60)$. Attempt at Commentary». Husserl Studies.

HUSSERL, E. Gesammelte Werke.

Hua III/1 (1976). Ideen zu einer reinen Phänomenologie und phänomenologischen Philosophie (Erstes Buch). The Hague: Martinus Nijhoff.

Hua VI (1954). Husserl, E., Die Krisis der europäischen Wissenschaften und die transzendentale Phänomenologie: Eine Einleitung in die phänomenologische Philosophie. The Hague: Martinus Nijhoff.

Hua VII (1956). Husserl, E., Erste Philosophie (1923/24). Erster Teil: Kritische Ideengeschichte. The Hague: Martinus Nijhoff.

Hua XXI (1983). Husserl, E., Studien zur Arithmetik und Geometrie (18861901). The Hague: Martinus Nijhoff.

Hua XXIV (1984). Husserl, E., Einleitung in die Logik und Erkenntnistheorie. Vorlesungen 1906/07. The Hague: Martinus Nijhoff. Eng. Transl.: Introduction to Logic and Theory of Knowledge: Lectures 1906-07, Hill, C.O. (Trans.), Dordrecht: Springer, 2008.

Hua XXV (1987). Aufsätze und Vorträge (1911-1921). Dordrecht: Kluwer Academic Publishers.

Hua XXVIII (1988). Vorlesungen über Ethik und Wertlehre 1908-1914. Dordrecht: Kluwer Academic Publishers.

Hua Mat I (2001). Logik Vorlesung 1896. Dordrecht: Kluwer Academic Publishers. 
Hua Mat II (2001). Logik Vorlesung 1902-3. Dordrecht: Kluwer Academic Publishers.

Hua Mat III (2001). Allgemeine Erkenntnistheorie 1902-3. Dordrecht: Kluwer Academic Publishers.

Hua Mat V (2002). Urteilstheorie Vorlesung 1905. Dordrecht: Kluwer Academic Publishers.

Hua Mat VII (2005). Einführung in die Phänomenologie der Erkenntnis. Dordrecht: Springer.

LANDGREBE, L. (1949). «Phenomenology and Metaphysics», Philosophy and Phenomenological Research, 10 (2): 197-205.

MAJOLINO, C. (2016). "Until the End of the World": Eidetic Variation and Absolute Being of Consciousness - A Reconsideration». Research in Phenomenology, 46 (2): 157-183.

MARBACH, E. (2010). «Is There a Metaphysics of Consciousness Without a Phenomenology of Consciousness? Some Thoughts Derived from Husserl's Philosophical Phenomenology», Royal Institute of Philosophy Supplement, 67: 141-154.

MoRAn, D. (2005). Edmund Husserl: Founder of Phenomenology. Cambridge: Polity Press.

TRIZIO, E. (2016). «What is the Crisis of Western Sciences?». Husserl Studies, 32(3): 191-211.

ZAHAVI, D. (2001). «À propos de la neutralité métaphysique des Recherches logiques». Revue Philosophique de Louvain, 99 (4): 715-736.

- (2002). «Transcendental Subjectivity and Metaphysics». Husserl Studies, 25: $103-116$.

— (2010). «Husserl and the 'Absolute'». In: C. Ierna, H. Jacobs, and F. Mattens (eds.). Philosophy, Phenomenology, Sciences. Dordrecht: Springer, 71-92.

ZAHAVI, D. and D. Boucher (2008). «Phénoménologie et Métaphysique». Les Etudes philosophiques, 4: 499-517.

EMILIANO TrizIO (MPhil London School of Economics 2001, PhD Paris-X/Ca' Foscari University Venice, 2005) has taught at the University of Paris Pantheon Sorbonne, at the University of Lille III, and at the University of Seattle. He is 
currently Senior Lecturer of Philosophy at the University of the West of England, Bristol. After working, on the one hand, on mainstream philosophy of science, and, on the other, on the phenomenological account of natural sciences, he has subsequently turned to the study of the relations existing between phenomenology, metaphysics, and philosophy of history. At the moment, he is also exploring the roots of phenomenology in ancient Greek thought. Most recent publications: What is the Crisis of Western Sciences?, Husserl Studies, 32(3): 191-211; Edmund Husserl between Platonism and Aristotelianism, D. De Santis, E. Trizio (Eds.), The New Yearbook for Phenomenology and Phenomenological Philosophy, XV, 2017. Routledge: London and New York. 